\title{
Determinants of Islamic Banks' Profitability in Indonesia
}

\author{
N D P Rini' ${ }^{1}$ D I Burhany ${ }^{2}$ \\ \{Noerdwipurnamarini@gmail.com ${ }^{1}$,dian.imanina@polban.ac.id $\left.{ }^{2}\right\}$ \\ ${ }^{1,2}$ Applied Master of Islamic Finance and Banking, Bandung State Polytetchnic, Indonesia
}

\begin{abstract}
This research aims to examine the determinants of Islamic Banks' profitability in Indonesia, consisting of internal and external factors. The research method is descriptive verificative. The research sample is 12 Islamic Commercial Banks that publish their financial statements for period 2013-2017. Data research is secondary data that is the annual financial reports published by Bank Indonesia and Financial Services Authority or OJK for variables CAR, NPF, BOPO, FDR; the annual Islamic Commercial Bank report for variable ROA; the annual report of Bank Indonesia and Indonesian Central Bureau of Statistics for variables BI Rate and Inflation. This panel data, a combination of cross-section and time series, analyzed using regression analysis method. The study result found that internal factors CAR and NPF have positive effect on ROA, while BOPO and FDR have negative effect on ROA. Meanwhile, external factors BI Rate and Inflation have no effect on ROA.
\end{abstract}

Keywords: Return On Assets (ROA), Capital Adequacy Ratio (CAR), Net Performing Financing (NPF), Operational Expenses per Operating Income (BOPO), Financing to Deposit Ratio (FDR), BI Rate, Inflation

\section{Introduction}

Indonesia is a country with the largest Muslim population in the world. By involving the Muslim population, Indonesia is a potential market in developing Islamic finance. One of which is now starting to develop rapidly, namely with banks whose operational activities use sharia principles. Islamic banking in Indonesia is projected to increase rapidly in line with the rapid expansion and acceleration of the growth of Islamic banking assets which is very high and coupled with the increasing volume of Sukuk using data obtained from the Islamic Finance Country Index (IFCI) (kompasiana.com).

The main objective of bank operations is to achieve a maximum level of profitability. Profitability is the ability of banks to generate/earn profits effectively and efficiently [1]. There are several measures of profitability, including Return on Equity (ROE) and Return On Assets (ROA). ROE is a measurement for returns obtained from investments in companies [2]. While ROA is a ratio calculated by dividing net income from the total assets. ROA has been used in most studies to measure bank profitability. ROA measures the profits derived from assets and reflects how well 
bank management uses bank investment resources that actually generate profits [3]. In determining the soundness of a bank, Bank Indonesia prioritizes ROA rather than ROE because Bank Indonesia prioritizes the value of bank profitability as measured by assets whose funds come from public savings funds so that ROA is more representative in measuring the level of bank profitability. The greater the ROA of a bank, the greater the level of profit achieved by the bank and the better the bank's position in terms of asset use[4].

Profitability, as measured by ROA is expressed as a function of internal factors and external factors. Internal determinants are factors that are mainly influenced by management decisions and bank policy objectives. Internal factors in question are the Capital Adequacy Ratio (CAR), Net Performing Financing (NPF), Operational Expenses per Operating Income (BOPO), and Financing to Deposit Ratio (FDR). Whereas external factors are factors related to macroeconomics and do not have a direct relationship with bank management but will affect financial performance indirectly. The external factor in question is the BI Rate and Inflation [5]. The BI Rate is a policy interest rate that reflects the monetary policy stance or stance set by Bank Indonesia and announced to the public[6]. While inflation is interpreted as increasing prices in general and continuously. The price increase of only one or two items cannot be called inflation unless the increase extends (or results in an increase in prices) to other goods (www.bi.go.id, 2017). Milton Friedman said inflation is everywhere and is always a monetary phenomenon that reflects the existence of excessive and unstable monetary growth So, inflation is an event that shows an increase in the price level in general and goes on continuously.

Research on factors that affect bank profitability has been carried out by many previous researchers, such as) who found that CAR has a positive and significant effect on profitability while NPL has a negative impact on profitability and inflation has no significant effect; [7] found that CAR and FDR had a positive and significant effect on profitability while NPF, BOPO, and Inflation. Meanwhile, Kalengkongan [8] found that interest rates and inflation simultaneously had a significant effect on profitability. Then Noman, [9] found that credit risk and cost efficiency had a negative and significant effect, CAR and bank size had a positive and significant effect, GDP and interest rates had a negative but not significant effect on profitability.

Based on the description above, the purpose of this study is to determine the effect of internal determinants consisting of CAR, NPF, BOPO, and FDR and external determinants consisting of the BI Rate and Inflation, on profitability as measured by ROA.

\section{Literature Review}

\subsection{Effect CAR on ROA}

Capital Adequacy Ratio (CAR) is also commonly referred to as the capital adequacy ratio, which means the amount of own capital needed to cover the risk of losses arising from planting risk-bearing assets and financing all fixed objects and bank inventory. The greater the Capital Adequacy Ratio (CAR), the greater the bank profits. In other words, the smaller the risk of a bank, the greater the profits obtained by the bank [10]. The higher the CAR the better the performance of a bank. Optimal credit distribution, assuming no traffic jams will increase profits which will ultimately increase ROA The capital ratio (CAR) is increasing and with large capital, the 
opportunity to obtain company profits is also greater. The higher the CAR, the higher the ROA. So, CAR has a positive effect on ROA [11].

\subsection{Effect NPF on ROA}

Non-Performing Financing (NPF) is a ratio that shows the ability of banks to manage problem loans/financing given by banks, NPF is used as a measure of credit risk. High NPF will increase costs so that it has the potential to bank losses. The higher the ratio, the worse the quality of bank credit, which causes the number of problem loans to increase, and therefore the bank must bear losses in its operational activities so that it affects the decrease in profit (ROA) obtained by banks [12]. The higher the NPL, the greater the risk channeled by the bank so that the lower-income projected with Return On Assets (ROA) decreases. So, NPF has a negative effect on ROA.

\subsection{Effect BOPO on ROA}

The bigger the BOPO, the bank profitability will decrease. If the bank is running its operations efficiently by minimizing the BOPO ratio, the income earned by the bank will certainly increase and will also be offset by increased profitability [13]. If operational activities are carried out efficiently (in this case the value of the BOPO ratio is low), the income generated by the bank will increase. In addition, the magnitude of the BOPO ratio is also due to the high cost of funds raised and the low income from planting funds, so the greater the BOPO, the smaller the Return on Assets (ROA). So, BOPO has a negative effect on ROA [14].

\subsection{Effect FDR on ROA}

The FDR ratio is used to assess a bank's ability to meet liquidity needs and the adequacy of liquidity risk management. The greater this ratio indicates that the bank is more aggressive in its liquidity, on the contrary, the smaller the ratio is also the greater the third-party funds that are not used to place financing (a lot of unemployed funds) so that the return obtained by the bank is small. This high and low ratio will affect the level of profitability (ROA) of Islamic banks [14]. Financing to Deposit Ratio has a negative and significant effect on Return on Assets in banking companies. The greater the Financing to Deposit Ratio of banks will cause a decrease in Return on Assets in banking companies. So, FDR has a negative effect on ROA [9].

\subsection{Effect Inflation on ROA}

In the monetary sector, high and uncontrolled inflation can disrupt banking efforts in mobilizing public funds. This is due to the high inflation rate which causes the real interest rate to decline. Such facts will reduce the public's desire to save so that the growth of bank funds sourced from the community will decrease. High-level inflation will have an adverse effect on economic development. Costs that continue to rise cause productive activities to be very unprofitable. Thus changing the view of capital owners to speculate, among others by diverting it through the sector of fixed assets such as land, houses, and buildings, so that conditions like this will affect the level of profitability (ROA) of Islamic banks [14]. So, inflation has a negative effect on ROA [9]. 


\subsection{Effect BI Rate on ROA}

The BI Rate is a policy interest rate that reflects the monetary policy stance or stance set by Bank Indonesia and announced to the public. If the Bank Indonesia interest rate (BI Rate) rises, then this will be followed by an increase in deposit interest rates in conventional banks, so investors will tend to prefer to save their funds in conventional banks because they are tempted by high interest, in other words, the productivity of Islamic banks in the real sector it becomes low, because the funds raised by Islamic banks are few, so Islamic banks have difficulty channeling funds into the real sector, consequently bank productivity decreases because banks are burdened with high funding costs, so this situation will affect the bank's profitability (ROA) sharia [14]. BI interest rates (BI rate) also influence the profitability of banks. When the BI interest rate rises, it will be followed by an increase in deposit rates which has a direct effect on the decline of thirdparty bank funding sources. This decline in deposits was a result of transferring public funds to conventional banks to get higher interest rates. If the DPK falls, the profitability of Islamic banks will also decline [15]. So, interest rates negatively affect ROA [9].

\section{Method}

The research method used is descriptive verification method. Data sources are secondary data in the form of annual financial reports published by Bank Indonesia for the period 2013-2017 through the site ojk.go.id. data for CAR, NPF, BOPO, FDR, and ROA variables are obtained from the annual Islamic Commercial Bank report data. While the data for the BI Rate and Inflation variables are taken from the annual data of Bank Indonesia and the Indonesian Central Bureau of Statistics. The data used is panel data, which is a combination of cross-section data with time series, which are analyzed using regression analysis. The test used to determine the most appropriate technique for estimating panel data regression in this study is the common effect. Common Effect is the simplest technique for estimating panel data, which is only by combining time series data and cross-section. By combining these data without differences between time and individuals, the Ordinary Least Squares (OLS) method can be used to estimate the panel data model. This approach is called Common Effect, where it is assumed that the data behavior between companies is the same in various time periods. To test the feasibility of the regression model used, this study will be tested using the classic assumption test. The classic assumption test in this study consisted of the normality test, autocorrelation test, multicollinearity test, and heteroscedasticity test.

\section{Result and Discussion}

From the Lagrange test results obtained P-Value of 0.3079 which is greater than the error of 0.05. So that the Lagrange Multiplier Test shows that $\mathrm{HO}$ is accepted which means the best estimation method is the Common Effect. 


\subsection{Test Model (F Test)}

To find out whether or not a significant influence of the independent variables on an independent variable is used the $\mathrm{F}$ test. The results of the $\mathrm{F}$ test based on the processing of the Eviews software are presented in the following table:

\begin{tabular}{llll}
\hline \hline & & & \\
R-squared & 0.502883 & Mean dependent var & 0.678295 \\
Adjusted R-squared & 0.446606 & S.D. dependent var & 0.083551 \\
S.E. of regression & 0.062154 & Akaike info criterion & -2.609113 \\
Sum squared resid & 0.204747 & Schwarz criterion & -2.364773 \\
Log-likelihood & 85.27340 & Hannan-Quinn criter. & -2.513538 \\
F-statistic & 8.935795 & Durbin-Watson stat & 1.981398 \\
Prob(F-statistic) & 0.000001 & &
\end{tabular}

Tabel 1. Overall Thesis Testing (Uji F)

From the table above, the $\mathrm{F}$ value is calculated $(8.935795)>\mathrm{F}$ table $(2,275)$ and the significance value $\mathrm{F}$ is count $(0,000001)<0,05$, then $\mathrm{H} 0$ is rejected, meaning that there are significant effects $\mathrm{X} 1, \mathrm{X} 2, \mathrm{X} 3, \mathrm{X} 4, \mathrm{X} 5$, and $\mathrm{X} 6$ against $\mathrm{Y}$.

\subsection{Hypothesis Test (t-test)}

To find out whether or not a significant influence of the independent variables partially on an independent variable is used the $\mathrm{t}$-test. The results of the t-test are presented in the following table:

\begin{tabular}{crrrr}
\hline \hline Variable & Coefficient & Std. Error & t-Statistic & Prob. \\
\hline \hline C & 39.35210 & 10.33554 & 3.807455 & 0.0004 \\
X1_CAR & 0.001787 & 0.000889 & 2.009604 & 0.0496 \\
X2_NPF & 0.014091 & 0.003599 & 3.914868 & 0.0003 \\
X3_BOPO & -0.076666 & 0.026633 & -2.878574 & 0.0057 \\
X4_FDR & -126.1016 & 34.09117 & -3.698953 & 0.0005 \\
X5_INFLASI & -0.008293 & 0.009089 & -0.912381 & 0.3657 \\
X6_BI_RATE & 0.009525 & 0.016234 & 0.586733 & 0.5599 \\
\hline \hline
\end{tabular}

Tabel 2. partial thesis testing (Uji t)

Based on the table above the following results are obtained:

a. CAR variable has a value of $t$ count of 2.009604 and a significance value of 0.0496 . Because the value of $t$ count $(2.009604)>t$ table $(2.006)$ and the sig value $(0.0496)<0.05$ then $\mathrm{H} 0$ is rejected, meaning that there is a significant effect of CAR on ROA. Regression coefficients for independent variables $\mathrm{X} 1$ are positive indicating a unidirectional relationship between $\mathrm{X} 1$ and $\mathrm{Y}$. The regression coefficient $\mathrm{X} 1$ of 0.001787 implies that for every increase in X1 of one unit it will increase the ROA of 0.001787 and vice versa. The results of this study 
support Alharbi [16] which states that banks with large capital are safer than banks with low capital ratios because they have access to cheaper and less risky sources of funds, which leads to increased profitability.

b. The NPF variable has t count value of 3.914868 and significance value of 0.0003 . Because of the value of $t$ count $(3,914868)>t$ table $(2,006)$ and the sig value $(0,0003)<0,05$, then $\mathrm{H} 0$ is rejected, meaning that there is a significant effect of NPF on ROA. Regression coefficients for NPF independent variables are positive showing a unidirectional relationship between X2 and Y. NPF variable regression coefficient of 0.014091 means that for every NPF increment of one unit will cause an increase in ROA of 0.014091 and vice versa. The results of this study are in line with Aslam et al. [17] which states that financing has a positive and direct impact on profitability. Financing and investment lead to increased profitability. When banks invest in different projects and finance various customers increasing the bank's income, profitability increases. With increasing market share, monopoly power increases so that it can change product prices and generate profits.

c. BOPO variable has a value of $t$ count of -2.878574 and a significance value of 0.0057 . Because the value of $t$ count $(-2.878574)<-t$ table $(-2.006)$ and the sig value $(0.0057)<0.05$ then $\mathrm{HO}$ is rejected, meaning that there is a significant effect of BOPO on ROA. Regression coefficients for BOPO independent variables are negative indicating a unidirectional relationship between $\mathrm{X} 3$ and ROA. The BOPO variable regression coefficient of -0.076666 means that for each BOPO increase of one unit it will cause a decrease in ROA of 0.076666 and vice versa. The results of this study are in line with Hajer Zarrouk [18] and [19] which states that BOPO has a significant effect on ROA. Investors, as consideration for determining their investment strategies, will look at BOPO without ignoring other factors. In this case, BOPO is a comparison between operational costs and operating income in measuring the level of efficiency and ability of banks to carry out their operations. Therefore, with efficiency, especially cost efficiency, the optimal level of profit will be obtained, the increase in the number of funds channeled, more competitive costs, improved service to customers, increased banking security and health so investors can determine their investment strategies.

d. The FDR variable has a value of $t$ count of $-3,698953$ and a significance value of 0,0005 Because the value of $t$ count $(-3,698953)<-t$ table $(-2,006)$ and its sig value $(0,0005)<0,05$ then $\mathrm{HO}$ is rejected, meaning there is a significant effect of FDR on ROA. Regression coefficients for the BOPO independent variable are negative indicating a unidirectional relationship between FDR and ROA. The X4 variable regression coefficient of -126.10167 means that for every increase in FDR of one unit it will cause a decrease in ROA of 126.10167 and vice versa. The results of this study confirm Hidayati [20] and Asadullah [21] who stated that they can manage their liquidity management more effectively because initially, financial institutions began to introduce short-term financing options to fill out fullterm liabilities and cash obligations. More obligations remove part of the profitability of any organization because they have to pay interest and principal amounts every month or periodically. Very rare skills among financial institutions in Pakistan to benefit from obligations by implementing a feasible plan that will help to get the excess amount to pay off debt easily and maintain residual income. 
e. The BI Rate variable has a value of $t$ count of 0.586733 and a significance value of 0.5599 . Because the value of $t$ count $(0.586733)<t$ table (2.006) and the sig value (0.5599)>0.05 then $\mathrm{HO}$ is accepted, meaning that there is no significant effect of the BI Rate on ROA. Regression coefficients for positive BI Rate independent variables show a unidirectional relationship between BI Rate and ROA. The BI Rate variable regression coefficient of 0.009525 means that for each BI rate increase of one unit it will cause an increase in ROA of 0.009525 and vice versa. The results of the study confirm Wibowo [22] which states that although the interest rates of commercial banks have increased, the ROA in Islamic banks has not decreased significantly. This is caused by the first, sharia bank customers seem to be customers who are relatively loyal to Islamic banks. In this case, the main deposit customers of sharia banks are customers who tend to put forward on sharia principles with a small amount of application of the principle to get interested that is valued as usury. Second, mudharabah deposits are deposits whose funds can be deposited within a certain period of time. Thus customers who enter deposits must wait several periods to be able to take their deposits so that the effect of short-term interest rates does not seem to change the mudharabah deposits much

f. Inflation variable has a value of $t$ count of -0.912381 and a significance value of 0.3657 Because the value of $t$ count $(-0.912381)>-t$ table $(-2.006)$ and its sig value $(0.3657)>0,05$ then $\mathrm{HO}$ is accepted, meaning that there is no significant effect of inflation on ROA. Regression coefficients for independent variables Inflation are negative, indicating a unidirectional relationship between inflation and ROA. Regression coefficient Inflation variable of -0.008293 means for each increase Inflation of one unit will cause a decrease in ROA of 0.008293 and vice versa. The results of this study are in line with Asadullah [21] which states that inflation does not have a significant effect on ROA. Wibowo [22] states that basically, high inflation reflects an increase in goods which can reduce the value of money circulation due to rising prices. However, the negative impact of inflation does not seem to be significant at the level of 5\%. This shows that there is not much inflation to reduce deposits or savings in Islamic banks. This result suggests that there is little resistance to Islamic banks against inflation.

\subsection{Determination Coefficient Test}

To find out the magnitude of the influence of X1, X2, X3, X4, X5, and X6 on Y, the coefficient of determination is used. The test results are presented in the following table:

\begin{tabular}{llll}
\hline \hline R-squared & 0.502883 & Mean dependent var & 0.678295 \\
Adjusted R-squared & 0.446606 & S.D. dependent var & 0.083551 \\
S.E. of regression & 0.062154 & Akaike info criterion & -2.609113 \\
Sum squared resid & 0.204747 & Schwarz criterion & -2.364773 \\
Log likelihood & 85.27340 & Hannan-Quinn criter. & -2.513538 \\
F-statistic & 8.935795 & Durbin-Watson stat & 1.981398 \\
Prob(F-statistic) & 0.000001 & & \\
\hline \hline
\end{tabular}

Tabel 3. Determination Coefficient Test 
Based on the output results above, the $\mathrm{R} 2$ value is 0.502883 . This shows that the contribution of $\mathrm{X} 1, \mathrm{X} 2, \mathrm{X} 3, \mathrm{X} 4, \mathrm{X} 5$, and $\mathrm{X} 6$ to $\mathrm{Y}$ is $50.3 \%$ while the remaining $49.7 \%$ is the contribution of other variables besides X1, X2, X3, X4, X5, and X6 which are not examined in this study.

\section{Conclusion}

Based on the results of the study, it can be concluded as follows:

a. Simultaneously or together, internal determinants of CAR, NPF, BOPO, and FDR, as well as external determinants of the BI Rate and Inflation, affect ROA.

b. Partially, the determinants of internal CAR and NPF have a positive effect on ROA while BOPO and FDR have a negative effect on ROA. Meanwhile, the external determinants of the BI Rate and Inflation have no effect on ROA.

\section{Suggestion}

Based on the results of the research, the suggestions submitted by the authors to Islamic Commercial Banks in Indonesia are:

1. Sharia Commercial Banks should maintain CAR values to remain stable because high CAR values can reduce the level of profitability (ROA).

2. For the NPF problem, the banking management must maintain the performance of the existing NPF which is below the number 5, as long as the NPF value below 5 indicates that the bank is in a healthy condition.

3. Sharia Commercial Banks in Indonesia must maintain FDR as optimally as possible. The bank must continue to disburse funds to the community in accordance with the standards set by Indonesian banks but must maintain, potential profits that can be obtained by banks.

4. For further researchers, it is recommended to add internal and other external factors that affect the profitability of Islamic Commercial Banks, in order to obtain more comprehensive results.

\section{References}

[1] M. Kumbirai and R. Webb, "A financial ratio analysis of commercial bank performance in South Africa," African Rev. Econ. Financ., vol. 2, no. 1, pp. 30-53, 2010.

[2] L. J. Gitman and C. J. Zutter, Principles of Managerial Finance. Boston: Pearson Education, Inc., 2012.

[3] F. I. Sehrish Gul, "Factors Affecting Bank Profitability in Pakistan," Rom. Econ. J., 2011.

[4] L. Dendawijaya, Manajemen Perbankan. Jakarta: Ghalia Indonesia, 2005.

[5] P. Athanasoglou, M. Delis, and C. Staikouras, "Determinants of Bank Profitability in The South Eastern European Region,” 2006.

[6] "No Title."

[7] M. Said and H. Ali, "An analysis on the factors affecting profitability level of Sharia banking in Indonesia," Banks Bank Syst., vol. 11, no. 3, pp. 28-36, 2016.

[8] G. Kalengkongan, "Tingkat Suku Bunga dan Inflasi Pengaruhnya terhadap Return on Asset (ROA) pada Industri Perbankan yang Go Public di Bursa Efek Indonesia," J. EMBA 
J. Ris. Ekon. Manajemen, Bisnis dan Akunt., vol. 1, no. 4, 2013.

[9] A. H. M. Noman, M. M. Chowdhury, N. J. Chowdhury, M. J. Kabir, and S. Pervin, "The effect of bank specific and macroeconomic determinants of banking profitability: A study on Bangladesh,” Int. J. Bus. Manag., vol. 10, no. 6, p. 287, 2015.

[10] S. Kuncoro, Manajemen Perbankan: Teori dan Aplikasi. Yogyakarta: BPFE, 2001.

[11] O. Masood and M. Ashraf, "Bank - specific and macroeconomic profitability determinants of Islamic banks," Qual. Res. Financ. Mark., vol. 4, no. 2/3, pp. 255-268, Aug. 2012.

[12] Kasmir, Manajemen Perbankan. Jakarta: PT. Raja Grafindo Persada, 2004.

[13] A. Y. Prasanjaya and I. W. Ramantha, "Analisis pengaruh rasio CAR, BOPO, LDR dan ukuran perusahaan terhadap profitabilitas bank yang terdaftar di BEI," E-Jurnal Akunt., vol. 4, no. 1, pp. 230-245, 2013.

[14] M. Usnan, "Analisis Faktor-Faktor yang Mempengaruhi Return On Assets Pada Bank Umum Syariah dan Unit Usaha Syariah Periode 2010-2013)," JRKA, vol. Volume, no. 2, p. Isue., 2016.

[15] A. A. Karim, Bank Islam: Analisis Figh dan Keuangan. Jakarta: PT. Raja Grafindo Persada, 2006.

[16] A. T. Alharbi, "Determinants of Islamic banks' profitability: international evidence," Int. J. Islam. Middle East. Financ. Manag., vol. 10, no. 3, pp. 331-350, 2017.

[17] M. M. Shah Khan, F. Ejaz, and E. Aslam, "Determinants of Profitability of Islamic Banking Industry: An Evidence from Pakistan," Bus. Econ. Rev., vol. 6, no. 2, pp. 27-46, Oct. 2014.

[18] H. Zarrouk, K. Ben Jedidia, and M. Moualhi, "Is Islamic bank profitability driven by same forces as conventional banks?," Int. J. Islam. Middle East. Financ. Manag., vol. 9, no. 1, pp. 46-66, 2016.

[19] Erni Masdupi and Defri, "Pengaruh Capital Adequacy Ratio (CAR), Likuiditas dan Efisiensi Operasional Terhadap Profitabilitas Perusahaan Perbankan yang Terdaftar di BEI," J. Manaj., vol. 1, no. 1, 2012.

[20] H. Hidayati and Y. Yuvia, "Pengaruh Capital Adequacy Ratio (Car), Net Interest Margin (Nim), Loan To Deposit Ratio (Ldr) dan Non Performing Loan (Npl) Terhadap Return On Assets (Roa) Pada Pt. Bank Mandiri (Persero). Tbk.," Holist. J. Manag. Res., vol. 3, no. 3, pp. 37-51, 2015.

[21] M. Asadullah, "Determinants of Profitability of Islamic Banks of Pakistan - A Case Study On Pakistan's Islamic Banking Sector," in International Conference on Advances in Business, Management and Law, 2017.

[22] E. S. Wibowo and M. Syaichu, "Analisis pengaruh suku bunga, inflasi, car, bopo, npf terhadap profitabilitas bank syariah," Diponegoro J. Manag., vol. 2, no. 3, pp. 10-19, 2013. 